\title{
The influence of the SWOT analysis strategy on the achievement of the fifth preparatory literary class students' evaluative thinking at history.
}

\author{
Qasim Irzooqi Qasim, Assistant lecturer, Al-Imam Al-Kadhim College, qassim.razouki@alkadhum-col.edu.iq
}

\begin{abstract}
The present study aims to identify the influence of the SWOT analysis strategy on the achievement of the fifth preparatory literary class students' evaluative thinking at history. The researcher adopted the experimental design with partial control of the experimental and control groups and the post-test to achieve the objectives of the present study. The researcher randomly chose Section (B) to represent the experimental group that It is taught according to the SWOT analysis strategy, and Section (A) to represent the control group that is taught according to the traditional method. The number of the two research groups reached (62) students, of which (31) students were in the experimental group and (31) students were in the control group. The two groups were equalized in the variables, including the chronological age, the achievement of the fourth class at history, and the evaluative thinking. The two research tools; the achievement test and its validity and reliability were verified. The evaluative thinking test and its psychometric properties were verified. The researcher used the t-test ) For two independent samples for data processing. The results show the superiority of the experimental group over the control group in terms of achievement and evaluative thinking.
\end{abstract}

Keywords: SWOT analysis strategy, achievement at history, evaluative thinking.

Received: 07.12.2020 Accepted: 10.01.2021

Published: 06.02.2021

\section{The research problem}

The nature of the subject of history and its organization cause teaching history to face many problems. Most teachers use students based teaching methods that require memorization and indoctrination without enabling students to understand historical facts and information or to identify the interrelationships between events. Thus, this type of teaching leads to weakness of students' 'academic achievement. It also has a negative impact on students 'thinking patterns in processing information, including evaluative thinking. Complaints increased as a result of tautology in historical topics, the abundance of events in them, their ramifications, and their details because of the difficulty of understanding the subject and the abundance of historical terms and theoretical information, which caused students' aversion from learning history (AlAnbaki, 2001: 1).

The researcher identified the research problem by visiting a number of preparatory schools. He got acquainted with the reality of teaching history. The researcher conducted an interview with a number of teachers of history. The previous indicators reinforced the researcher's need to pay attention to teaching history to the fifth preparatory literary classes and raise their level of achievement as well as their evaluative thinking. It was also found that no local study was conducted to identify the influence of SWOT analysis strategy on achievement and evaluative thinking. Accordingly, the researcher believes that there is a problem that requires research through increasing efforts to develop better plans using better teaching methods. It is also an experimental attempt to identify the influence of the SWOT analysis strategy on achievement and evaluative thinking.

\section{The problem of the present study was identified as follows}

1. Is there a difference between using the SWOT analysis strategy and the traditional method in students' achievements at history in fifth preparatory literary classes?

2. Is there a difference between using the SWOT analysis strategy and the traditional method in evaluative thinking among fifth preparatory literary students?

The significance of the present study. 
Modern education emphasizes the interest in education as a system of planned behavior. This includes groups of purposeful activities that each teacher and learner undertakes. It contains three components with dynamic characteristics; (teacher, learner, and academic curriculum). Education is ineffective unless it is designed in a sequential and organized manner (Mari and Muhammad, 2010: 91).

(Hooper, 1993) believes that by using teaching methods that are based on intellectual dialogues, questions and answers, merging ideas, presenting the rationale for the lesson content, obtaining appropriate assumptions and comparing ideas among the learners, the educational process leads to a deeper treatment of the lesson content (Hooper, 1993: 7).

Therefore, modern educational strategies and methods appeared. They convey the effectiveness of the educational process from teachers to learners. So, the learner in this case is the center of organized activities aiming at achieving the goals of the educational process. In this case, learning is unforgettable. These strategies help the learner to self-learn (Melhem, 2006: 425).

A good teaching strategy is to enable interaction between the parties of the educational learning situation, determine the performance performed by both the learner and the teacher, and guide the lesson towards achieving the goal or solving a specific problem. The strategy with good characteristics increases social interactions between learners and develops emotional aspects. The teacher has a clear role, primarily, in the process of liaising with learners as a guide, facilitator, assistant, organizer, and source of ideas (Al-Barak, 2007: 105).

According to the SWOT analysis strategy, teaching facilitates the learning process and allows teachers to identify the extent to which the lesson objectives are achieved for learners. This improves the performance of the teachers and allows them to move from daily problems to strategies in teaching. The SWOT strategy raises the level of full awareness and supports strategic planning and decision-making to provide an accurate assessment of the educational situation by simplicity and application at different levels of education. This is an ideal way to increase awareness. It can be used to develop new strategies as it addresses internal weaknesses and external threats while taking advantage of the internal strengths and external opportunities of the educational situation (Wheelen \& Hunger, 2003: 23).

Thus, the researcher concludes that the SWOT analysis strategy is one of the effective strategies in teaching, which gives a positive role to the learner in the lesson as it leads to asking questions related to historical topics to make them meaningful as well as to organize and classify historical information and clarify the interrelations between them. Thus, it helps to Raise the level of learners' achievement.

Academic achievement is one of the educational achievements that institutions try make their students achieve. Awareness of the academic achievements of students is a good test for anticipating their future academic performance by those interested in evaluating student activity are enthusiastic about their efforts to improve the objectivity, stability, and relevance of student academic achievement (Nasrallah, 2010: 45).

As the acquisition of thinking styles can only be achieved through the adoption of teaching methods and strategies that help the learner to acquire and use information, the internal factors that affect learning, such as knowledge of the learner, etc. are acquired by focusing on what happens in the student's mind when exposed to the educational situation. That can raise the level of achievement, develop mental skills, develop previous thinking patterns, learning motivation ... etc. (Padilla, 1995: 6).

Evaluative thinking is one of the important thinking styles that the learner needs to acquire and develop his/her skill in academic subjects in general and history in particular.

Evaluative thinking develops skills that provide learners with a variety of evaluation methods. It explains evidence that can be used to provide information about problems and progress in solving problems to identify the criteria upon which decision-making is based. It is very important to provide the tools that are necessary to collect information in an organized manner to provide feedback on how to gain new experience (Bennett \& Jessani, 2011: 24).

To the best of the researcher's knowledge, no studies have dealt with the influence of the independent variable, the strategy of SWOT analysis on the dependent variables, achievement and evaluative thinking. So, lack of research related to this aspect must be taken into account To promote the teaching process and change its traditional character to a scientific method that leads to better objective results in the transition To one of the modern strategies. Thus, the researcher believes that it is important to improve achievement in history and achieve the acquisition of evaluative thinking among students.

The objectives of the present study. 
The present study aims to identify the influence of the SWOT analysis strategy on the achievement of the fifth preparatory literary class students and their evaluative thinking.

\section{The hypotheses}

1. "There is no statistically significant difference at the level of (05.0) between the average grades of the experimental group students who studied the history subject using the SWOT analysis strategy and the average scores of the control group students who studied the same history subject by the traditional method in terms of achievement."

2. "There is no statistically significant difference at the level of (05.0) between the average scores of the experimental group students who studied the history subject using the SWOT analysis strategy and the average scores of the control group students who studied the same history subject in the traditional method in terms of evaluative thinking.

\section{The limits}

The present study is limited to:

1. A sample of the fifth preparatory literary class students in Al-Jihad Secondary School for Boys at the General Directorate of Education in the province of Maysan for the second semester of the academic year (2018/2019).

2. Chapters (Fifth, Sixth and Seventh) (Modern and Contemporary History of Europe and America) from the preparatory Literary History textbook for the Fifth year, Eleventh Edition, Ministry of Education/ Republic of Iraq.

\section{Defining terms}

1. The SWOT strategy; Gomer \& Hille, 2015) define it as a systematic teaching tool designed to help improve performance in education, increase potential, reduce risks, and work to make better decisions and help determine the effectiveness of any small or large act such as the educational situation through which performance can be improved in the learning process (Gomer \& Hille, 2015: 1).

(Embu Saidi et al, 2019) define it as a strategy based on students studying the phenomenon from multiple aspects to determine its strengths, then identifying weaknesses, identifying available opportunities, and finally threats, opportunities, and future things that can be external (Embu Saidi et al., 2019: 333).

The procedural definition; The researcher defines it as a four-way analysis strategy consisting of four components: Strength, the strength component of the historical topic or event that distinguishes it from other topics and analyzes the weaknesses in the historical topic or event, and the opportunities that can come from outside the topic or historical event." It may lead to an increase in knowledge and risks that may come from outside the topic or historical event and cause the formation of a wrong alternative for students of the experimental group of the research sample.

2. The evaluative Thinking; Buckley et al. (2015) define it as a type of critical thinking applied in the context of evaluation, out of curiosity and knowledge about the value of evidence, through definition of assumptions, planned questions, reflection and decision-making in preparation for action, and participation in the pursuit of a deeper understanding of the situation (Buckley et al, 2015: 375).

(Irzouki et al, 2018) define it as a mental process that aims at making decisions about the value and quality of ideas and accessing alternatives through the ability to make better choices (Irzouki et al. 2018: 38).

The procedural definition; The researcher defines evaluative thinking as a pattern of critical thinking that takes decisions according to its three basic skills: finding the criteria upon which the decision-making process is based, proving the accuracy of the claim, and logical recognition and identifying errors or misunderstandings included and procedurally measured according to the degree obtained by the students of the study sample when They answer the items of the evaluative thinking test prepared for this study.

3. Achievement; It is defined as the learning occurrence of the students in the educational experience that appears through the degree of success of the strategy set by the teacher to achieve his/her goals and the knowledge that the student will reach (Zaghoul and Mahameed, 2007: 87).

(Attia, 2008) defines it as the learner's progress towards achieving pre-defined educational goals (Attia, 2008: 300). 
The procedural definition; It is measured by what students learned in the fifth literary class after studying the history course, and the overall result that the student obtains in the achievement test prepared for the present study.

The fifth preparatory grade; It is the fifth level of the secondary stage, whose by six levels that come after the primary stage and precede the university stage according to the school system in the Republic of Iraq (Ministry of Education, 1993: 11).

\section{The theoretical background}

The theoretical background includes two subsections that are devoted to tackling the SWOT analysis strategy and the evaluative thinking.

\section{First: The SWOT Analysis Strategy}

The SWOT strategy helps learners study phenomena and events from multiple perspectives by identifying strengths, weaknesses, opportunities, threats and future external risks. It can be implemented as it corresponds to topics that require multifaceted research (Embu Saidi et al., 2019: 333). SWOT analysis is a teaching strategy that provides information through analysis. It is divided into (advantages and disadvantages) and external problems and factors (opportunities and threats) (Ifediora \& Nzekwe, 2014: 23). The SWOT analysis strategy is to plan learning situations that provide a vision with specific goals to strengthen the activities of the educational process, improve its weaknesses, and show its strengths in order to inspire new achievements. The emergence of the SWOT analysis strategy coincides with the increase in education and its expansion and increasing with the difficulties that faced education in the last century when enrollment rates began to increase, the demographics of students began to change, and the difficulty of teaching some subjects began to appear. So, the SWOT strategy came as a solution to develop a proactive stance for the effectiveness of education (Hinton, 2012: 56). The main goal of the SWOT strategy is to achieve a balance between the desired topics and the external environment and maintaining this balance over time. The educational situation can achieve this balance by evaluating topics and events with the intention of increasing the level of achievement (Harrison, 2010: 92).

\section{The components of the strategy}

The strategy consists of four components:

1. Strengths; It is a component of the strength of the strategy that distinguishes it from other teaching strategies. It is an attribute that allows teachers to accomplish educational tasks, which are features within the topic or a task to implement the educational situation and the final success in achieving it. Strengths can be tangible or intangible.

2. Weaknesses; They are weaknesses in the subject and they are related to internal factors that may hinder the achievement of learning outcomes. The increase in these weaknesses affects the success and growth of the learner. Weaknesses are factors that do not meet the standards that must be adhered to. Weaknesses can be controlled, reduced or eliminated, including Weaknesses in terms of blurring of the topic, lack of skills, etc.

3. Opportunities; These opportunities can come from outside the topic. For example, they may come from external factors that can lead to an increase in information and can allow increased learning opportunities for the student, which helps to achieve specific planned goals. These opportunities can occur for teachers to take advantage of the conditions of their environment to plan and implement educational procedures that enable them to be more effective in the teaching process. Teachers need more awareness in seizing opportunities as they arise.

Opportunities come in the form of better reviews, competitive advantages and a better alignment with the learning process.

4. Threats; Threats come from outside the topic and they can cause confusion in the topic that arises when external environmental conditions threaten the reliability of information in educational situations. The threat also leads to association with weaknesses, which causes an increase in the vulnerabilities of the subject as these threats cannot be controlled when they occur. If the idea, topic, or evidence includes some important potential threats to be analyzed, then general negative images present as a result of the ever-changing techniques in dealing with events (Khamova, 2013: 3).

5. 


\section{Steps of the strategy}

1. The teacher chooses the topic carefully and precisely for discussion and analysis.

2. He/she creates the SWOT strategy table.

3. He/she writes the general topic for analysis and discussion.

4. The teacher then completes the teaching process (Frangeaheim, 2005: 43).

5. The teacher begins clarifying what is meant by the analysis according to the SWOT strategy and its four components for students.

6. The teacher distributes a paper that includes a table of the SWOT analysis strategy to the students. Then, he/she asks them to analyze the topic from its four aspects beginning with strengths and identifying the positive aspects, then diagnosing weaknesses and identifying the negative aspects. After that, they must build a future idea and complete the table by identifying the available opportunities to benefit and finally identifying the threats that may hinder the implementation of the idea or the analysis of the topic.

7. The teacher can provide the the students the opportunity to first identify strengths and discuss them, then identify weaknesses and discuss them, opportunities, and threats that affect the topic and increase its weakness.

8. The teacher facilitates students' work while doing the analysis according to the SWOT analysis strategy.

9. The teacher begins with a group discussion, exchange of views, and a dialogue with students after the analysis process ends (Ambo Saeedi et al, 2019: 334).

\section{Second: The evaluative Thinking.}

It is the mental activity that aims to judge the value of ideas and things, their completeness, quality, and ability to evaluate, which is the possibility of access to decisions and judgment on standards, solutions and alternatives, and evaluation to choose the best of them. Evaluative thinking deals with the basic explanatory process in which the student must participate and conduct discussions to reach decisions. In turn, this has a great influence on solving the problem (Schwandt, 2002: 18).

\section{Requirements of evaluative thinking.}

Evaluative thinking requires critical analysis of educational topics through the following:

It asks important and specific questions.

The learner identifies the data necessary to answer the specific question posed.

It collects information using the right strategy.

It analyzes the collected data.

It summarizes the results.

It utilizes the result in the required learning process (Baker and Bruner, 2012: 1).

Skills of evaluative thinking.

It consists of three basic skills which are:

A. Establishing the criteria upon which the decision-making process is based, including:

Identifying key issues, defining key assumptions, evaluating assumptions, anticipating business outcome, tracking information, and developing an alternative planning strategy.

\section{Proving the validity of the claim.}

Determining the reliability of the source by verifying the reliability of the written reference, including the reputation of the author or writer, its accuracy, discipline, and the degree of agreement between him/her and other sources, and verifying that there is no personal interest or purpose behind his/her work.

Watching and judging the reports of observations.

Investigating bias and stereotypes.

Learning about biased languages.

Classification of information.

Determining the reason for stating the situation and why it is stated.

Comparing the similarities and differences.

Evaluating discussion or evidence.

C. Identifying logical errors or misunderstandings, their definition, and application.

Identifying the difference between facts and opinions.

Getting acquainted with the information related to the topic. 
Identifying weak thinking or erroneous conclusions (Jarwan, 2007: 73).

\section{Areas of Evaluative Thinking}

Areas for evaluative thinking are:

1. Values.

Evaluative thinking begins with specific social and disciplinary values and standards that act as catalysts for evaluation of the topic or phenomenon to be studied.

2. Perceptions.

Perception addresses the internal thinking process by imparting the meaning in which the learner is required to evaluate the subject, along with the cultural norms that guide how he/she deals with the evaluation process.

3. Applications.

Carrying out evaluation procedures for the purpose of their application, and using methods to collect data and information and conducting analyzes related to the event.

4. Evaluation results.

Issuing judgments, making decisions, and assigning merit at the level of evaluation by stating the importance of the event or phenomenon and its impact (Vo et al. 2018: 38).

\section{Applying evaluative thinking}

1. Creating a learning environment through works that include evaluative thinking skills such as wall papers, creating educational stations and presenting questions and assumptions on wall paintings.

2. Presenting tasks that require evaluative thinking skills by making learners obtain information about assumptions by classifying results according to the required priorities, conducting discussions to verify assumptions and ensuring their accuracy and correctness, conducting critical dialogues on neutral topics and avoiding emotional charging, and doing critical review and defining assumptions.

3. Planning activities that encourage evaluative thinking by having learners analyze the topics and determine the assumptions involved in the topic to be analyzed by addressing the various perspectives and conducting evaluation simulations through data collection and analysis with evaluation strategies that learners follow.

4. Cooperative learning of evaluation thinking skills, which is done by dividing students into cooperative groups working on creating models and logical diagrams that include evaluative thinking skills and changing the schemes according to the requirements of each topic.

5. Presenting and discussing learners' work by reviewing the presented business models and assisting in identifying the logical paragraphs, assumptions, and strengths of their assumptions.

6. Encouraging learners to contribute to the practice of evaluative thinking by making all evaluation work and topics be based on the participation of all students at all levels and have the opportunity to contribute their views (Buckley et al, 2015: 380).

\section{METHODOLOGY AND PROCEDURES}

The semi-experimental approach was adopted to achieve the objectives. The experimental design of the experimental and control groups was adopted, with partial control of the post-test for the achievement of history and evaluative thinking. The following diagram illustrates this.

Table 1.

\begin{tabular}{|l|l|l|l|}
\hline The two research groups & Independent variable & Post test & Dependent variable \\
\hline Experimental & SWOT analysis strategy & $\begin{array}{l}\text { Achievement and } \\
\text { evaluative thinking tests }\end{array}$ & $\begin{array}{l}\text { Achievement and } \\
\text { evaluative thinking }\end{array}$ \\
\hline Control & Traditional method & & \\
\hline
\end{tabular}

The research sample; Al-Jihad Secondary School for Boys at the General Directorate of Education in the province of Maysan was intentionally selected to conduct the research for the cooperation of the school administration with the researcher in the application of the research as well as the presence of more than one section for the fifth preparatory literary class. Section (B) formed of (31) students, which is the experimental group and section (A) consisting of (31) students, which represents the control group. 


\section{Equivalence of the two groups}

The researcher equalized the two groups in the number of variables that may affect the results of the research, which are equivalence in the age in months for students of the two groups and previous achievement in the history course for the fourth preparatory literary class and the evaluative thinking test. The researcher applied it to students of the research sample before the experiment for equivalence. The results indicate the equivalence of the two groups in these variables as shown in Table (1).

Table 2. Equivalence of the two groups and the T-value of the approved equivalence variables.

\begin{tabular}{|c|c|c|c|c|c|}
\hline \multirow[t]{2}{*}{ Variables } & \multicolumn{2}{|c|}{$\begin{array}{ll}\text { The } & \text { experimental } \\
\text { group(31) }\end{array}$} & \multicolumn{2}{|c|}{ The control group(31) } & \multirow[t]{2}{*}{$\begin{array}{l}\text { Calculated } \mathrm{T} \text { - } \\
\text { value }\end{array}$} \\
\hline & $\begin{array}{l}\text { Arithmeti } \\
\text { c mean }\end{array}$ & $\begin{array}{l}\text { Standard } \\
\text { deviation }\end{array}$ & $\begin{array}{l}\text { Arithmetic } \\
\text { mean }\end{array}$ & $\begin{array}{l}\text { Standard } \\
\text { deviation }\end{array}$ & \\
\hline Age/month & 200.21 & 6.453 & 201.259 & 7.147 & 0.607 \\
\hline $\begin{array}{l}4^{\text {th }} \quad \text { grade } \\
\text { achievement } \\
\text { at history }\end{array}$ & 60.155 & 3.454 & 59.852 & 4.258 & 0.308 \\
\hline $\begin{array}{l}\text { Evaluative } \\
\text { thinking test }\end{array}$ & 20.942 & 2.104 & 21.118 & 2.569 & 0.295 \\
\hline
\end{tabular}

Table (1) shows that the calculated T-value for all the variables in which the equivalence was conducted is less than the tabular T-value of (2) at a degree of freedom of (60) and a level of significance of (05.0). This indicates that it is not statistically significant and confirms that the experimental and control groups are equivalent In these variables.

\section{Requirements and sources of information}

Determining the learning material; The material has been determined and it represents the second part of the history textbook; Modern and Contemporary Europe and America) from the History textbook for the fifth preparatory literary class, eleventh edition, (2018), Ministry of Education, Republic of Iraq.

1. Chapter Five.

First World War.

2. Chapter Six.

International situations between the two world wars.

3. Chapter Seven.

World War II.

\section{Daily lesson plans and (behavioral goals)}

The daily lesson plans for the two groups were formulated depending on the subjects of the educational subject. (15) daily plans were formulated for teaching for each group. These plans included the behavioral objectives related to teaching the targeted research topics. The topics were analyzed according to Bloom's levels of knowledge; (rememberance, understanding, And application, analysis, synthesis, and evaluation). It reached (200) behavioral objectives that were presented to the arbitrators of the specialization in methods of teaching of history.

The research tools.

\section{The first tool: The achievement test}

Preparation of the specification table.

The specification table is a blueprint for the distribution of the items of the achievement test in light of the educational content and the behavioral objectives that the test measures. For this, the researcher prepared a table of specifications for the topics that the researcher studied during the period of the experiment as indicated in Tables (2) and (3). 
Table 3. Number of objectives for each level

\begin{tabular}{|l|l|l|l|l|l|l|l|l|}
\hline No. & $\begin{array}{l}\text { Content, } \\
\text { chapters }\end{array}$ & Knowledge & Comprehension & Application & Analysis & Synthesis & Evaluation & Total \\
\hline 1 & Fifth & 26 & 19 & 2 & 7 & 4 & 2 & 60 \\
\hline 2 & Sixth & 27 & 23 & 5 & 9 & 3 & 3 & 70 \\
\hline 3 & Seventh & 33 & 22 & 5 & 3 & 3 & 4 & 70 \\
\hline 4 & Total & 86 & 64 & 12 & 19 & 10 & 9 & 200 \\
\hline
\end{tabular}

Table 4. Test items using the test map.

\begin{tabular}{|c|c|c|c|c|c|c|c|c|c|}
\hline \multirow{2}{*}{$\begin{array}{l}\text { Chapte } \\
\text { rs }\end{array}$} & \multirow{2}{*}{$\begin{array}{l}\text { Number } \\
\text { of } \\
\text { objectiv } \\
\text { es } \\
\end{array}$} & \multirow{2}{*}{$\begin{array}{l}\text { Relative } \\
\text { importan } \\
\text { ce }\end{array}$} & \multicolumn{6}{|c|}{ Levels of objectives } & \multirow{2}{*}{$\begin{array}{l}\text { Tot } \\
\text { al }\end{array}$} \\
\hline & & & $\begin{array}{l}\text { Knowled } \\
\text { ge } \\
43 \% \\
\end{array}$ & $\begin{array}{l}\text { Understand } \\
\text { ing } \\
32 \% \\
\end{array}$ & $\begin{array}{l}\text { Applicati } \\
\text { on } \\
6 \% \\
\end{array}$ & $\begin{array}{l}\text { Analys } \\
\text { is } \\
9 \%\end{array}$ & $\begin{array}{l}\text { Synthe } \\
\text { sis } \\
5 \% \\
\end{array}$ & $\begin{array}{l}\text { Evaluati } \\
\text { on } \\
4 \%\end{array}$ & \\
\hline First & 60 & $30.23 \%$ & 5 & 4 & 1 & 1 & 1 & 0 & 12 \\
\hline Second & 70 & $31.40 \%$ & 5 & 4 & 1 & 1 & 1 & 0 & 12 \\
\hline Third & 70 & $38.37 \%$ & 7 & 5 & 1 & 1 & 1 & 1 & 16 \\
\hline Total & 200 & $100 \%$ & 17 & 13 & 3 & 3 & 3 & 1 & 40 \\
\hline
\end{tabular}

\section{Drafting of the test items}

As the objective question is selected from the multiple choice type, the researcher created test items for each behavioral purpose according to the cognitive level in the specification table. Multiple choice is one of the important types within the objective tests. It is used to distinguish them with depth of thinking and distinguish the similarities. The guessing factor in them is low. The reliability is extremely high.

In this type, the researcher followed the pattern of the one correct answer that consists of a basic phrase followed by four alternatives to the answer, one of which is correct and the others are false. The test included (30) items to measure levels of (knowledge, understanding,, and application. The second half of the test includes the type of essay question , Which is characterized by the ability to measure many diverse abilities, especially cognitive abilities (analysis, synthesis, and evaluation). The test consists of (10) paragraphs of the short essay type, so that a good test is the one that combines the objective and essay paragraphs as it combines the advantages of the two types and limits The disadvantages of relying on one of them.

Validity of the test; The validity of the test was confirmed as follows:

External validity; The researcher presented the test to a group of arbitrators in teaching methods, measurement, and evaluation to demonstrate the validity of the test items. According to those opinions, $80 \%$ was approved for acceptance of the paragraph. All the paragraphs were approved after making some proposed amendments to them. So, the test consisted of (40) paragraph s.

Validity of the content; The approval of the specification table to set a sample of questions that represent the educational content and the behavioral objectives that it seeks to achieve is in itself an accreditation of the content's validity. The test is considered valid in terms of content if its items obtain an agreement percentage of (75\%) or more than the judges 'estimates (Al-Dhahir, 1999: 134).

Test correction; The researcher assigned a score of (1) for the correct answer and (0) for the wrong answer, as well as for the missed answer, such as the wrong answer. The first question whose highest score is (30) and the lowest score of (0). The second question consists of (10) which represents The grades for correction which are graded between $(0-3)$ for each paragraph. On this basis, the upper score for the overall test was (60) and the minimum score was (0). 


\section{Exploratory application of the test}

1. Sample time calculation and clarity of test items and instructions.

The researcher applied the test to a sample of fifth grade literary students in Al-Murtadha High School for Boys. The number of students was (25) students. They were notified before a specific period before the date of the exam. The examination process was supervised by the subject teacher. The students 'inquiries were few, which confirms the clarity of the paragraphs of the test and its instructions. The time for answering the test was (54) minutes. It was extracted using the arithmetic mean.

2. Statistical analysis of the test.

To extract the characteristics of the test (difficulty coefficient, strength of discrimination, effectiveness of alternatives), and reliability coefficient, the test was applied to an exploratory sample chosen randomly from fifth-grade literary students at Maytham Al-Tammar Secondary School for Boys. (100) students participated. It was corrected according to a previously prepared correction key. The grades were arranged in descending order. $27 \%$ of the highest scores were taken to represent the highest group and $27 \%$ of the lowest scores to represent the lowest group. The number of members of each group reached (27) students, and a total of (54) students in the two groups.

3. The difficulty of the paragraphs.

The difficulty of the paragraphs ranged between (0.41-0.57) for the substantive paragraphs and (0.67-0.81) for the article paragraphs. The values of the level of difficulty are acceptable according to (Bloom, 1971), who indicates that $0-80,0$ ) is acceptable (Bloom, 1971: 66).

Tables (4) and (5) illustrate this.

4. Distinction

The distinction for the test items ranged between $(0.41-0.89)$ for the substantive paragraphs and (0.44-0.63) for the essay paragraphs as in Tables (4) and (5).

This means that all the test items are good.

Table 5. Difficulty and distinction of paragraphs in the upper and lower group.

\begin{tabular}{|l|l|l|l|l|}
\hline \multirow{2}{*}{ No } & \multicolumn{2}{|l|}{$\begin{array}{l}\text { Number of answers in the two } \\
\text { groups }\end{array}$} & Difficulty & Distinction \\
\cline { 2 - 3 } & $\begin{array}{l}\text { The upper } \\
\text { group answers }\end{array}$ & $\begin{array}{l}\text { The lower } \\
\text { group answers }\end{array}$ & & \\
\hline 1 & 22 & 7 & .54 & .56 \\
\hline 2 & 23 & 2 & .46 & .78 \\
\hline 3 & 21 & 6 & .50 & .56 \\
\hline 4 & 25 & 4 & .54 & .78 \\
\hline 5 & 20 & 3 & .43 & .63 \\
\hline 6 & 20 & 2 & .41 & .67 \\
\hline 7 & 22 & 6 & .52 & .59 \\
\hline 8 & 23 & 2 & .46 & .78 \\
\hline 9 & 21 & 3 & .44 & .67 \\
\hline 10 & 21 & 5 & .48 & .59 \\
\hline 11 & 23 & 2 & .46 & .78 \\
\hline 12 & 21 & 6 & .5 & .56 \\
\hline 13 & 25 & 1 & .48 & .89 \\
\hline 14 & 21 & 3 & .44 & .67 \\
\hline 15 & 23 & 2 & .46 & .78 \\
\hline 16 & 23 & 5 & .52 & .67 \\
\hline 17 & 21 & 2 & .43 & .70 \\
\hline 18 & 24 & 7 & .57 & .63 \\
\hline 19 & 22 & 3 & .46 & .70 \\
\hline 20 & 20 & 5 & .46 & .56 \\
\hline 21 & 17 & 6 & .53 & .41 \\
\hline 22 & 21 & 6 & .41 & .56 \\
\hline 23 & 19 & 3 & & \\
\hline & & & & .59 \\
\hline
\end{tabular}




\begin{tabular}{|l|l|l|l|l|}
\hline 24 & 19 & 5 & .44 & .52 \\
\hline 25 & 21 & 4 & .46 & .63 \\
\hline 26 & 26 & 2 & .52 & .89 \\
\hline 27 & 23 & 2 & .46 & .78 \\
\hline 28 & 21 & 3 & .44 & .67 \\
\hline 29 & 22 & 4 & .48 & .67 \\
\hline 30 & 22 & 2 & .44 & .74 \\
\hline
\end{tabular}

Table 6. The difficulty and distinction of the essay paragraphs test for the upper and lower groups.

\begin{tabular}{|l|l|l|l|l|l|l|l|l|l|l|l|}
\hline $\begin{array}{l}\text { Second } \\
\text { question }\end{array}$ & \multicolumn{9}{l|}{ Group answers } & \multicolumn{9}{l|}{ Lower group answers } & Difficulty & \\
\hline & \multicolumn{9}{|l|}{ Upper group answers } \\
\hline & 0 & 1 & 2 & 3 & 0 & 1 & 2 & 3 & & \\
\hline 1 & 0 & 9 & 7 & 11 & 9 & 8 & 6 & 4 & .81 & .44 \\
\hline 2 & 2 & 7 & 6 & 12 & 9 & 9 & 8 & 1 & .77 & .50 \\
\hline 3 & 3 & 6 & 9 & 9 & 10 & 9 & 6 & 2 & .72 & .44 \\
\hline 4 & 2 & 7 & 5 & 13 & 12 & 10 & 3 & 2 & .72 & .63 \\
\hline 5 & 2 & 8 & 8 & 9 & 11 & 8 & 5 & 3 & .72 & .44 \\
\hline 6 & 1 & 7 & 10 & 9 & 12 & 7 & 6 & 2 & .73 & .54 \\
\hline 7 & 2 & 5 & 9 & 11 & 11 & 5 & 9 & 2 & .79 & .50 \\
\hline 8 & 1 & 6 & 8 & 12 & 11 & 7 & 7 & 2 & .79 & .57 \\
\hline 9 & 2 & 5 & 7 & 13 & 9 & 8 & 8 & 2 & .81 & .52 \\
\hline 10 & 2 & 8 & 8 & 9 & 14 & 6 & 6 & 1 & .67 & .56 \\
\hline
\end{tabular}

A. The effectiveness of the wrong alternatives.

B. The statistical treatment of the data revealed that the wrong alternatives of the achievement test items attracted more students from the lower group than the higher group students. So, it was decided to keep all of them without deletion or modification.

Stability; The Kuder Richardso20 equation was adopted for objective questions (multiple choice) that the reliability coefficient extracted in this equation is an internal stability coefficient, which means the extent of homogeneity of the paragraphs among them. The value of the coefficient of stability was (0.88). According to the stability of the essay test using the (Alpha-Cronbach) equation, the value of the stability factor was (0.80) (Al-Nabhan, 2004: 240).

\section{Second: Evaluative Thinking}

Determining the objective of the test; This test aims to determine the influence of the SWOT analysis strategy on the evaluative thinking (the research sample) of the fifth-grade literary students in the present study.

Determining the test skills; The researcher identified three basic skills mentioned in the literature for the formulation of the evaluative thinking test, which are:

Creating criteria or standards for the decision-making process.

\section{Proving the accuracy of the claim}

Identifying errors and misunderstandings and defining them logically.

Preparing the paragraphs of the evaluative thinking test; The researcher prepared the paragraphs of the evaluative thinking test according to the following:

Relying on theoretical assumptions derived from the theoretical background of the present study, reviewing the History of Modern and Contemporary Europe and America textbook scheduled for the fifth literary grade, eleventh edition (2018), Ministry of Education, Republic of Iraq to be used in drafting the test items, which consisted of (3) basic skills. Two paragraphs were written for each sub-skill:

A. Creating criteria or standards for the decision-making process, including:

Identifying the central issues and defining the problem. There are two paragraphs about this sub-skill.

Determining the basic assumptions; There are two paragraphs about this sub-skill.

Evaluating assumptions; There are two paragraphs about this sub-skill. 
Expecting results based on an action; There are two paragraphs about this sub-skill.

Information following up; Two paragraphs were written for this sub-skill.

Planning alternative strategies; Two paragraphs were written for this sub-skill.

B. Proving the accuracy of the claim, including:

Determining the reliability of the source by verifying the reliability of the reference. Two paragraphs were written for this sub skill.

Judging observation reports; Two paragraphs were written for this sub-skill.

Investigating biases, patterns, and frivolous ideas; Two paragraphs were written for this sub skill.

Determining which language is based on evoking emotion; Two paragraphs were written for this sub skill.

Classification of information; There are two paragraphs about this sub-skill.

Determining the reason for stating the situation and why it is stated; There are two paragraphs about this sub skill.

Comparing the Similarities and Differences; There are two paragraphs about this sub-skill.

Evaluating the arguments or evidence and assessing the debate; Two paragraphs were written for this subskill.

C. Identifying mistakes and misunderstandings and defining them logically.

Differentiating between facts and opinions; Two paragraphs were written for this sub-skill.

Identifying the information that are relevant to the topic; Two paragraphs were written for this sub-skill.

Identifying weak mental reasoning or false conclusions; Two paragraphs were written for this sub-skill.

Four alternatives were formulated for each paragraph. One of them is correct only. So, the test consists of (34) paragraphs of multiple choice type. One score is given for the paragraph if the student chooses the correct alternative. A score of (zero) is given for the wrong alternative. The highest overall score for the evaluative thinking test is (34) Degrees. The lowest score is zero.

Validation of the test.

To ensure the validity of the test, the following points explain:

External validity; The test of evaluative thinking was presented to a group of arbitrators in measurement, evaluation, and teaching methods to judge the validity of the paragraphs in the evaluative thinking test. The researcher adopted $(80 \%)$ or more agreement percentage as a criterion for the validity of the paragraphs. The wording of some paragraphs was modified.

Instructions for answering the evaluative thinking test; Instructions for answering the test items were prepared, in which the purpose of the test, the number of test items, the type of paragraphs and alternatives, the method for answering the test questions, and the correction instructions were developed with specific answers for all the test items.

\section{Exploratory application of the test}

1. Sample time calculation and clarity of test items and instructions.

The researcher applied the test to (25) students from Maytham Al-Tammar Secondary School for Boys. They have the same research sample specifications.

Statistical analysis of the test.

The evaluative thinking test was applied to the statistical analysis sample of (100) students from Maytham AlTammar Secondary School for Boys taken from the research community. The upper group consisted of (27) students. The lower group consisted of (27) students.

A. The difficulty of the test items.

The researcher calculated the difficulty factor of each paragraph of the evaluative thinking test by using the difficulty equation. The difficulty factor of the evaluative thinking test items ranged from (0.5-0.66). Thus, it becomes clear that all the evaluative thinking test items have good difficulty.

B. Distinction of the test items.

The researcher calculated the distinctive strength of each of the 34 paragraphs of the evaluative thinking test. It was found that it ranges between (0.57-0.74). It became clear that all the paragraphs of the evaluative thinking test are distinguished according to the (Eble) standard that a good paragraph is the one that has more distinctive strength than (0.20) (Eble, 1972: 399). Accordingly, all the evaluative thinking test items are with good distinctive strength.

C. The effectiveness of (false alternatives). 
It was calculated and found that it was all negative. It attracted more students from the lower group than the students of the higher group. Thus, it was considered effective. Therefore, the alternatives were kept as they are.

\section{Stability of the test}

To calculate the reliability of the evaluative thinking test, the (Kuder - Richardson-20) equation was used because the reliability coefficient extracted by this equation is an internal stability coefficient, which is the homogeneity of the paragraphs (Abu Allam, 2005: 156). The internal consistency reached (89).

The finalized test; It consists of (34) items. Each paragraph has four alternatives. One of them represents the correct answer. A score of (1) is given for the correct alternative. A score of (0) is given for the wrong alternative. Thus, the total score on all items of the evaluative thinking test was (34) degrees. The lowest score was (zero) degree.

\section{Final application of the two research tools}

After completing the research experiment, the achievement test was applied for the two research groups (experimental and control) at the same time after informing students of the test date a week before the day specified for it, and the evaluative thinking test was applied for the two research groups (experimental and control) at the same time.

\section{Statistical means}

The researcher used the appropriate statistical means in the present study procedures, analyzing their data, and using the statistical program (SPSS) as follows:

The t-test for two independent samples, the difficulty equation, the paragraph distinction equation, the false alternatives efficacy equation, the Kiodor - Richardson equation 20 and the Alpha Cronbach equation.

\section{RESULTS AND INTERPRETATIONS}

The first hypothesis; By comparing the test results in the achievement of the experimental and the control groups, it was revealed that the mean of the experimental scores was (55.12), while the mean of the control scores was (30.91). Empirical, Table No. (6).

Table 6 . T-test for the two groups in the achievement test

\begin{tabular}{|l|l|l|l|l|l|l|l|}
\hline Group & $\begin{array}{l}\text { Samp } \\
\text { le }\end{array}$ & Arithmetic mean & $\begin{array}{l}\text { Standar } \\
\mathrm{d} \\
\text { deviatio } \\
\mathrm{n}\end{array}$ & T-value & & $\begin{array}{l}\text { Degree of } \\
\text { freedom }\end{array}$ & $\begin{array}{l}\text { Level of } \\
\text { significan } \\
\text { ce }\end{array}$ \\
\hline $\begin{array}{l}\text { Experimen } \\
\text { tal }\end{array}$ & 31 & 55.12 & $\begin{array}{l}\text { Calculat } \\
\text { ed }\end{array}$ & $\begin{array}{l}\text { Tab } \\
\text { ular }\end{array}$ & & \\
\hline Control & 31 & 30.91 & 5.497 & 16.139 & 2 & 60 & $\begin{array}{l}\text { Significan } \\
\text { t }\end{array}$ \\
\hline
\end{tabular}

Table (6) shows that the calculated T-value is (16.139), which is greater than the tabular T-value of (2), the degree of freedom is (60), and the significance is (05.0). There is a statistically significant difference in favor of the experimental group. So, the null hypothesis is rejected. The result is that the SWOT analysis strategy in teaching has a positive influence on increasing the achievement of the experimental group, that is, it is better than the traditional method of teaching. The student undertakes self-activity by interacting with the stages of the strategy and the questions associated with it, which strengthens his/her role in discussion and answering questions in the form of an interactive dialogue in organizing information through awareness and the process of internal thinking about complex and interrelated issues in the achievement of historical information.

The second hypothesis; By comparing the test results for the two groups, the mean scores of the experimental group were found to be (32.53) and the mean of the control group's scores was (22.13). The T- 
test was used for independent samples to find the difference between the two averages. A statistically significant difference appeared in favor of the experimental group.

Table 7. Results of the post evaluative thinking test

\begin{tabular}{|l|l|l|l|l|l|l|l|}
\hline $\begin{array}{l}\text { The two } \\
\text { research groups }\end{array}$ & Sample & $\begin{array}{l}\text { Arithmetic } \\
\text { mean }\end{array}$ & $\begin{array}{l}\text { Standard } \\
\text { deviation }\end{array}$ & T-value & D.H & $\begin{array}{l}\text { Significance } \\
0.05\end{array}$ \\
\hline & & & & Calculated & Tabular & & \\
\hline Experimental & 31 & 32.53 & 4.452 & 8.313 & 2 & 60 & \\
\hline Control & 31 & 22.13 & 5.357 & & & & \\
\hline
\end{tabular}

Table (7) shows that the calculated T-value is (8.313), which is greater than the tabular T-value of (2) DH (60) in terms of (05.0). This indicates a statistically significant difference in favor of the experimental group. So, the second null hypothesis is rejected. It turns out that the use of the SWOT analysis strategy in teaching has a positive influence on the evaluative thinking of the experimental group. It works to activate the distinction between facts and opinions of students. The skills of evaluative thinking seem simple in learning and teaching students, but in return, it requires high mental processes and requires careful planning. It has to identify the skills that students use in extracting the ideas and using them as a starting point for education in an attempt to link assumptions with new knowledge and use them as links to the content of the subject to be learned. Activity and competition during learning contribute to evaluative thinking through active and critical interaction between students with the subject and the teacher, the strategy of SWOT analysis, and the sense of performing duties effectively, increasing optimism and self-confidence. Students' evaluative thinking was achieved as a result of creating an appropriate psychological and educational climate for its development, which requires means and tools that are necessary for students to practice activities in the exchange of interactive dialogue and the ability to debate and express opinions.

\section{CONCLUSIONS}

Teaching with a SWOT strategy helps raise students' achievement in history by exploring and interpreting a rich set of texts, analyzing evidence, making observations, and application.

Teaching with the SWOT strategy develops the evaluative thinking of the students of the experimental group through the practice of observation, distinction, and judgment on the reliability of the evidence.

The inclusion of the strategy on educational procedures gives students the flexibility and fluidity of evaluative thinking in building knowledge and using their skills effectively.

\section{RECOMMENDATIONS}

1. High school history teachers should be interested in using this strategy because of its importance in developing students 'skills and abilities in deduction, analysis, and discussion, and increasing their capabilities in formulating questions and using them in new situations.

2. The designers of tests and metrics should pay attention to building evaluative thinking skills tests for the curricula of social studies, especially the history subject in secondary education, to be easy for teachers to use.

3. It is necessary to include in-service training course programs for history teachers on educational strategies that are consistent with teaching evaluative thinking skills, especially the SWOT strategy.

\section{Suggestions}

1. Conducting a study to find out the influence of SWOT strategy on achievement of other school subjects.

2. Conducting a study to find out the influence of SWOT strategy with other variables such as the acquisition of historical concepts, the tendency towards the teaching profession and other dependent variables. 


\section{REFERENCES}

Ambosaidi et al, (2019) Teacher Strategies for Effective Teaching, Jordan, Al Masirah House for Publishing and Distribution.

Jarwan, F. (2007) Teaching Thinking Concepts and Applications, 3rd edition, Dar Al-Fikr Publishers and Distributors, Amman.

Republic of Iraq, Ministry of Education, General Directorate of Curricula, (2019) (Modern and Contemporary History of Europe and America) for the Fifth Literary grade, 11th edition, Baghdad.

Ali S. (2007) Language and Critical Thinking, Foundations of Teaching Theory and Strategies, 1st edition, Dar Al-Masirah for Publishing and Distribution, Amman.

Irzouki, R., Nabeel, M. and Dhamia, D. (2018) The Series of Thinking and Its Patterns (-4-), Dar Al-Kutub AlIlmiyya, Beirut.

Al-Zaghoul, I. and Al-Mahamid, S. (2007) The Psychology of Classroom Teaching, Dar Al-Masirah for Publishing, Distribution and Printing, Amman.

Al-Dhahir, Z. (1999) Principles of Measurement and Evaluation in Education, House of Culture, Amman.

Attia, M. (2008) Modern Strategies in Effective Teaching, 1st edition, Safaa Publishing House, Amman.

Al-Anbaki, S. (2002) the influence of using the strategies of Clausmeyer, Millerotnosson, and Heldataba concepts on the development of inferential thinking and the acquisition and retention of historical concepts among students of the fourth preparatory classes at high schools in the subject of history, An unpublished PhD dissertation, Faculty of Education (Ibn Rushd), University of Baghdad.

Marei, T. and Muhammad, M. (2010) Teaching singlization, 2nd edition, Dar Al-Fikr for Publishing and Distribution, Amman, Jordan.

Melhem, S. (2006) The Psychology of Learning and Teaching, 1st edition, Dar Al Masirah for Publishing and Distribution, Amman, Jordan.

Al-Nabhan, M. (2004) Fundamentals of Evaluation in the Behavioral Sciences, Dar Al-Shorouk, Amman.

Nasrallah, O. (2010) Fundamentals in Practical Education, 2nd edition, Dar Wael, Amman.

Ministry of Education (1993) Ministry of Education Guide for Secondary Education, Republic of Iraq.

Harrison, J. (2010) Strategic Planning and SWOT Analysis. In J. Harrison, Essentials of Strategic Planning in Healthcare (pp. 91-97). Health Administration Press. Available on line on https://www.ache.org/pdf/secure/gifts/Harrison_Chapter5.pdf.

Bakeer, A., \& Bruner, B. (2012) The evaluative capacity into organizational.

Bennett, G. and Jessani, N. (2011) The Knowledge Translation Toolkit, Bridging the Know - Do Gap: AResource for Researchers, International Development Research Center.

Belom, B. S. (1971) Hand book on Formative and Summative Evaluation of Student Learning, New York, McGraw-Hill Book Com.

Buckley, J., Archibald, T., Hargraves, M., \& Trochim, W. M. (2015) Defining and teaching evaluative thinking: Insights from research on critical thinking. American Journal of Evaluation, 36 (3), 375-388.

Ebel, R. (1972) Essential of Educational Measurement, 2nd ed, New Jersy, Englewood.

Frangeaheim, E. (2005) classroom thinking strategies: Practical strategies to encourage thinking in your classroom. Paul Chapman Educational Publishing.

Gomer, J., \& Hille, J. (2015) SWOT ANALYSIS. Lecturer at the University of California.

Hinton, K. (2012) A Practical Guide to Strategic Planning in Higher Education. Society for College and University Planning (SCUP).

Hooper, T. (1993) The influence of Cooperative Learning and Learner Control on High - and Average-Ability Students", Educational Teaching Research and Development, Vol. : 41, No. : 2.

Ifediora, C., Idoko, O., \& Nzekwe, J. (2014) Organization's stability and productivity: the role of SWOT analysis an acronym for strength, weakness, opportunities and threat. International Journal of Innovative and Applied Research, 2 (9), 23-32.

Khamova, S. (2013) Weaknesses in the Process of English Language Teaching. International Journal of Humanities and Social Science, 3 (20), 33-36.

Padilla, m. (1995) Scieneep rocess skills, resechma hers to thesience leacher a Publicacationo f the narstno. $9004(11)$.

Schwandt, T. (2002) Evaluation Practice Reconsidered. New York, NY: Peter Lang Publishing. 
Vo, A. T. \& Martin (2018) Conceptual of evaluative thinking. In A. T. Vo \& T. Archibald (Eds.), Evaluative Thinking .. 158, 29-47.

Wheelen \&, H. J. D., T. L. (2003) Essentials of strategic management (Vol. 9). NJ: Prentice Hall. 